\title{
Economic Activity Expanding More Rapidly
}

\author{
Government Influence Very Stimulative
}

ost economic indicators accelerated markedly from May to August, and apparently the automobile strike in September has not materially slowed the advance. Spending, production, employment, and income have all turned upward in recent months. This faster pace of activity has been fostered by very expansionary fiscal and monetary conditions. The sharper growth in total spending at a time when underlying demands were already strong is placing greater upward pressures on prices and interest rates.

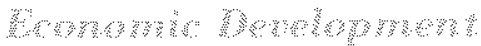

Consumers, businesses, and governments have all recently increased their demands for goods and servm ices. Retail sales have risen at about a 15 per cent annual rate since May, after going up about 5 per cent in the previous twelve months.

The expansion in sales has followed a period when purchases by ultimate users were already relatively large. Demand for goods and services, except for inventory change, rose at an 8.5 per cent rate in the first half of this year, a pace which ultimately places upward pressure on prices in view of a capacity growth trend of about 4 per cent per year. Preliminary data also show a high rate of expansion in final sales dur. ing the third quarter.

Reflecting both the pickup in sales and a better balance between business inventories and sales, industrial production turned up during the summer. From June to August industrial output went up at a 10 per cent annual rate and remained at a high level in September despite a major strike. By contrast output contracted at an average 3 per cent rate from October last year to June. Production has now regained the level of a year ago.

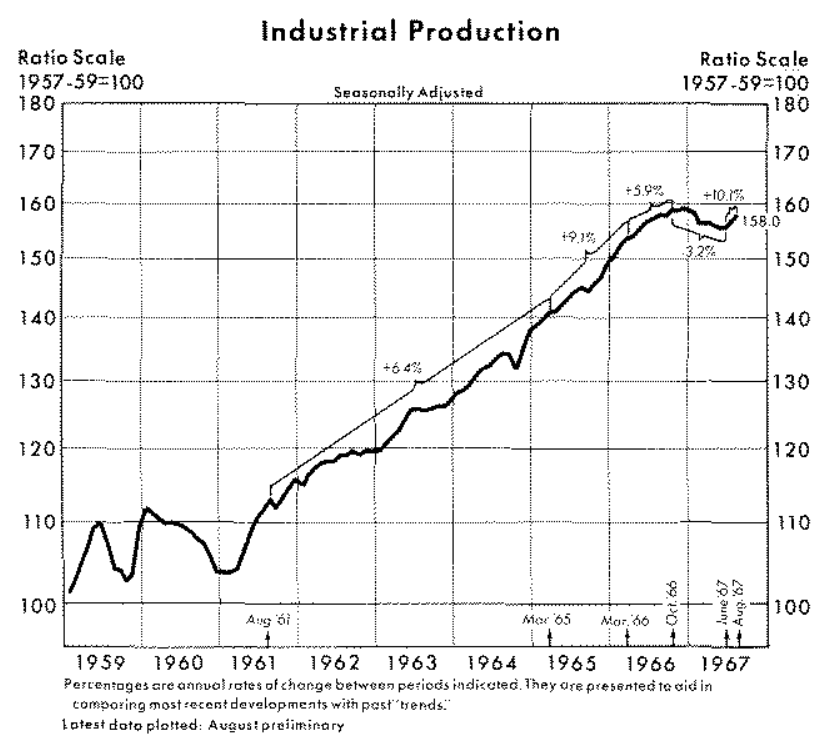

To facilitate the recent increase in total economic output, producers have hired workers at a rapid pace. Total employment has risen at about a 6 per cent rate since late Spring, after changing little earlier in the year. Payroll employment has increased at a 4 per cent rate from May to August, following little change from January to May. Unemployment has decreased slightly, but most of the new workers have come from an expansion in the labor force. Since population of working-force age is rising at only a 1.5 per cent a year rate, the rise in employment has been accomplished 
primarily by drawing into the labor force a large number of persons who were not formerly working or seeking work.

As employment and economic activity in general have risen, income has also gone up. Total personal income increased at a 9 per cent rate from May to August. Income rose 7 per cent in the previous twelve months and at a 6 per cent trend rate from 1957 to 1966.

Although strengthening of total demand has been accompanied by additional real output, prices have also increased. Price increases have reflected the rising costs associated with excessive demands for total product a year ago. Consumer prices increased at a 4 per cent annual rate from April to August after rising at a 2 per cent rate during the previous eight months. The recent acceleration was primarily in food prices. Prices of all consumer items except food have increased at a 3 per cent annual rate since April, virtually the same as the rate of the previous eight months.

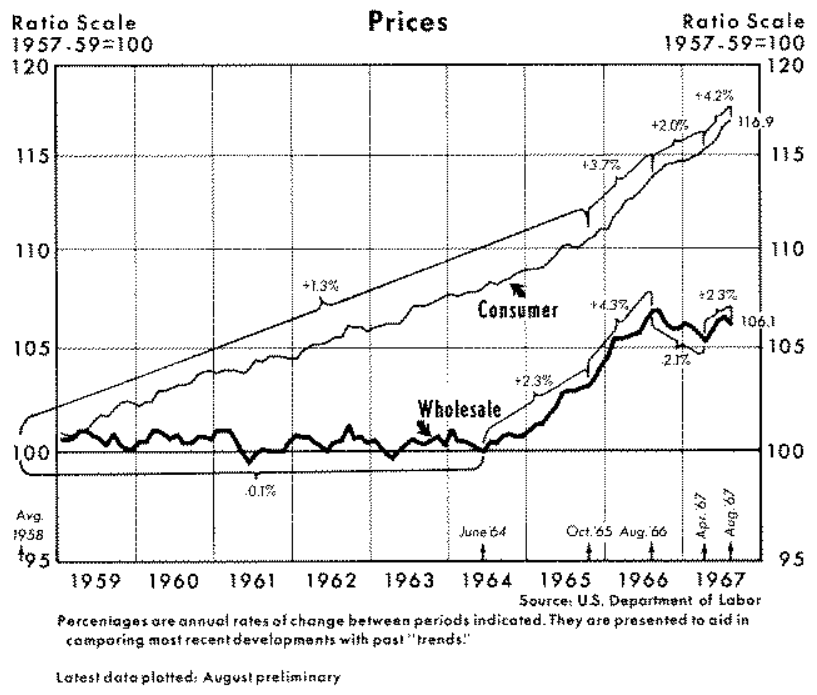

Wholesale prices, reflecting in considerable measure developments in agricultural products and processed foods, have increased at a 2.3 per cent annual rate from April to August. This index had fallen at a 2 per cent rate from last August to April. Wholesale prices of finished industrial goods have risen at a 1.5 per cent rate since April, about the same as in the previous eight months.

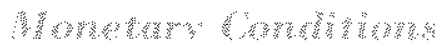

Monetary expansion has been rapid since the beginning of the year. Member bank reserves, a key monetary variable which includes both deposits at Reserve Banks and cash in vault and which provides a base for both bank credit and the money supply, have gone up at an 11 per cent annual rate in the past nine months. This increase compares with a 5 per cent average rate of growth from 1964 to 1966 and a trend rate of 3 per cent from 1957 to 1964 . Member bank reserves, in turn, are largely determined by Federal Reserve credit. This credit, adjusted for changes in reserve requirements, has increased at a 12 per cent rate in the past nine months.

The nation's money stock, which consists of private demand deposits and currency in the hands of the public, has risen at a 7 per cent annual rate in the last nine months. This is the fastest rate of increase for any nine-month period in over twenty years. Usually there has been an acceleration of spending within a few months after a marked and sustained increase in the growth rate of money. Money grew at a 4 per cent rate from 1964 to 1966 and at a 2 per cent trend rate from 1957 to 1964 .

Money plus time deposits in commercial banks, a broader concept of money, has also risen rapidly. Since last December this measure has increased at a 12 per cent annual rate compared with an 8 per cent rate from 1964 to 1966 and a 5 per cent rate from 1957 to 1964.

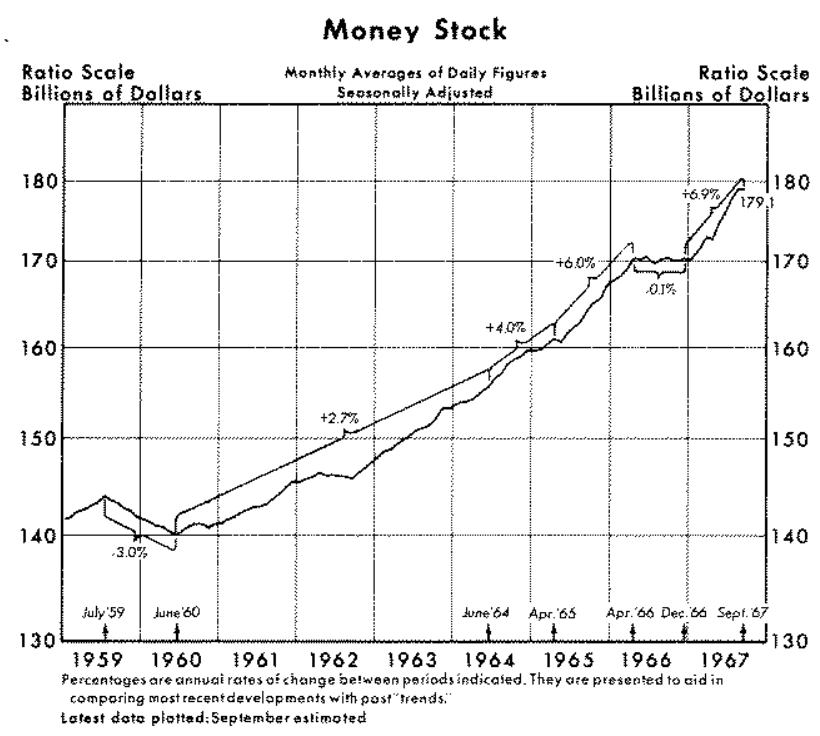

Bank loans and investments have been rising sharply this year. From December to August, total commercial bank credit rose at a 14 per cent annual rate. By comparison, this credit had essentially no increase from July 1966 to last December and rose at a 7 per cent average rate from 1957 to 1966 . Bank loans rose at a 7 per cent rate from December to May. Since May, when business activity began quickening, they have gone up at an 11 per cent rate. With bank reserves 


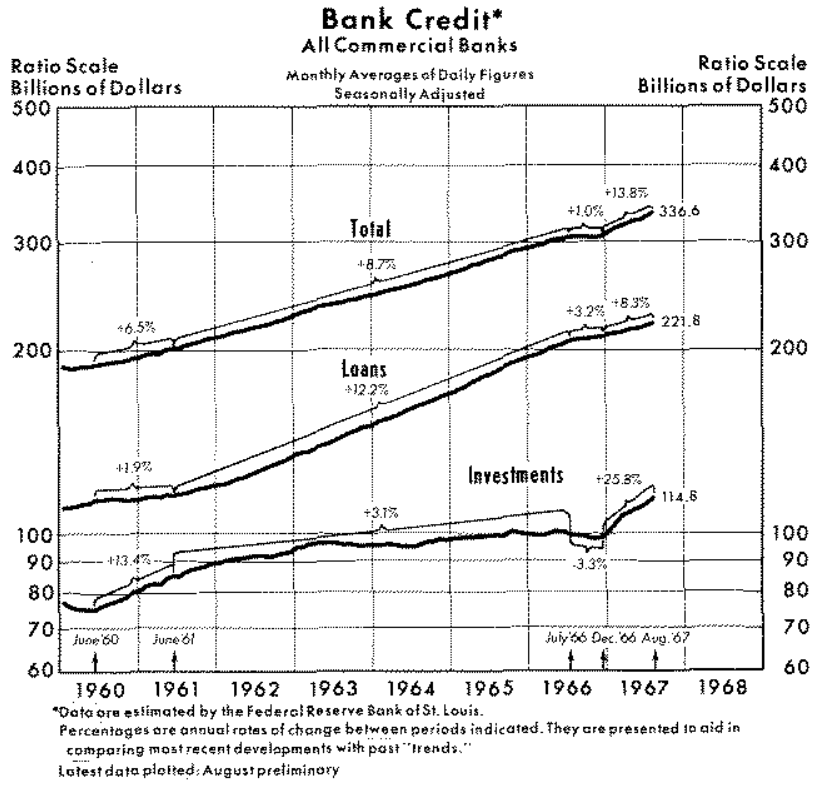

going up faster than customer demands for loans, the recent sharp rise in bank credit has centered in net purchases of securities. Consequently bank investment portfolios have risen at a 26 per cent rate since December, compared with a 3 per cent trend growth rate from 1957 to 1966 .

Most interest rates have risen in recent months and are at relatively high levels. A large amount of this increase reflects not only strength in demands for goods and services but also anticipatory demands for credit. A year ago interest rates were relatively high, but yields in the various maturity ranges have changed significantly since then. Short-term yields, which are most directly affected by bank credit expansion, are substantially lower than a year ago. Yields on threemonth Treasury bills were about 4.50 per cent in early October, down from 5.36 per cent in September a year ago.

On the other hand, interest rates on most long-term obligations, which are thought to be heavily influenced by market expectations of future rates, are now well above their year-ago levels. Rates on highest-grade corporate bonds averaged 5.72 per cent in early October, compared with the 5.49 per cent peak in September 1966. Yields on medium-grade corporate securities averaged 6.45 per cent in early October, up from 6.09 per cent in September last year.

\section{Merel conthints}

Large increases in Government spending have been adding more to the spending stream since mid-1965 than taxes and other Governmental receipts have been withdrawing. Defense spending has increased at a 22 per cent average annual rate since mid-1965, and has risen from 7.3 per cent of gross national product in the second quarter of 1965 to about 9.5 per cent in the third quarter of 1967. By comparison, defense outlays accounted for 10 per cent of GNP in 1957.

Nondefense expenditures have also expanded rapidly, accelerating an upward trend. Federal spending for purposes other than defense has risen at a 13 per cent average annual rate since mid-1965, or from 10.5 per cent of GNP to about 11.7 per cent. In 1957 this type of spending amounted to 8 per cent of GNP.

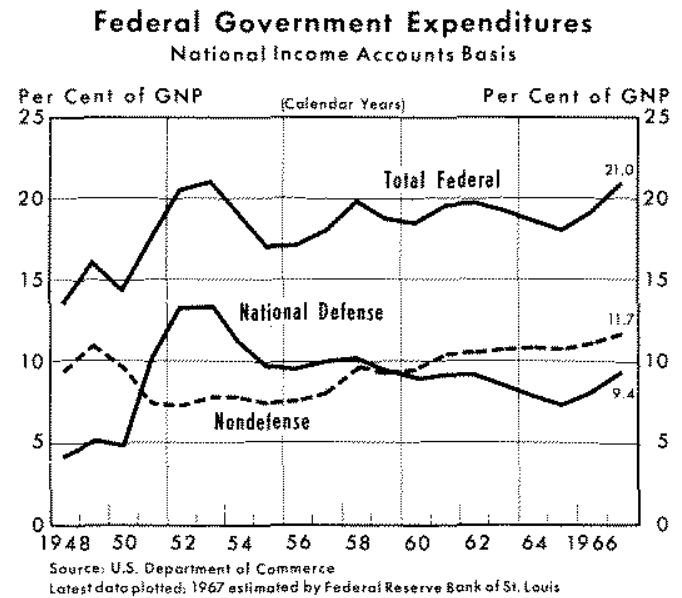

Fiscal stimulus in the first three quarters of 1967 continued to stem from the spending side of the budget as expenditures increased at an estimated 15 per cent annual rate from fourth quarter 1966 to third quarter 1967. Growth in federal receipts slowed in the first three quarters of 1967 , largely reflecting declines in corporate profits. To the extent that receipts reflect a slowdown in the rate of increase of taxable income, a rising deficit does not indicate expansionary fiscal action. However, after adjusting for the effects of economic activity on the budget by computing a standardized high-employment estimate, ${ }^{1}$ fiscal actions were still quite expansionary in the first three quarters of 1967. The deficit in the high-employment budget increased from $\$ 5$ billion in late 1966 to an estimated $\$ 12$ billion in third quarter of 1967 .

Prospects for the rest of 1967 are for a continuation of large deficits and further fiscal stimulus to the economy. Federal spending for defense and other purposes is expected to continue its advance despite efforts to cut outlays, and there now appears little likelihood that a tax increase will take effect before January 1, 1968.

1 For an explanation of the high-employment budget concept, see the June 1967 issue of this Review, pp. 6-14. 